\title{
Effects of prolonged elevated water salinity on submerged macrophyte and waterbird communities in Swartvlei Lake, South Africa
}

\author{
IA Russell ${ }^{* *}$ and RM Randall ${ }^{1,2}$ \\ ${ }^{1}$ South African National Parks, PO Box 176, Sedgefield, 6573, South Africa \\ ${ }^{2}$ Current address: 15 Faure Street, Sedgefield, 6573, South Africa
}

\begin{abstract}
Large fluxes in the physico-chemical characteristics of estuarine lakes can have profound effects on biota and processes. Where salinity in Swartvlei Lake usually ranges between 5 and 12, extended open conditions post-2007 floods, coupled with reduced freshwater inflows due to drought, resulted in salinity exceeding the upper tolerance of dominant submerged macrophytes. A resulting die-back of macrophytes equated to a $99 \%$ decline in standing crop, and was followed by a $95 \%$ decline in the biomass of waterbirds. Significant positive correlations exist between the biomass of macrophytes and both piscivorous and herbivorous waterbirds. Whereas Swartvlei Lake is expected to, in the short term, revert to its former (pre-2007 flood) state, inevitable environmental changes such as global warming and resulting changes in local climatic and marine conditions, along with increased freshwater abstraction from feeder rivers, could cause the observed large fluctuation in the abundance of aquatic biota to become more frequent.
\end{abstract}

Keywords: Swartvlei Lake, estuarine lake, drought, flood, macrophyte senescence, biotic interactions, environmental change, global warming

\section{INTRODUCTION}

Estuarine submerged macrophyte communities can be highly variable at both spatial and temporal scales, with many studies from around the world describing community changes along spatial and temporal salinity gradients (Verhoeven, 1975; Bayley et al., 1978; Verhoeven and van Vierssen, 1978a, b; Vaquer and Heurteaux, 1989; Lazar and Dawes, 1991; Quammen and Onuf, 1993). In South African estuarine systems, substantial community changes occurring in conjunction with elevated salinity have been recorded, mostly in estuarine lakes (Whitfield, 1984; Cyrus et al., 2011).

Only 8 estuarine lake systems occur in South Africa (Whitfield, 1995), which, considering that there are in excess of 250 estuaries in the country (Van Niekerk and Turpie, 2012), makes them relatively uncommon ecosystems. What estuarine lakes lack in number, however, they make up for in size, collectively comprising more than $62 \%$ of estuarine area in the country (Van Niekerk and Turpie, 2012). Most have a high conservation value, with 5 of the 8 ranking in the top 10 estuaries in South Africa in terms of conservation importance, and with 7 of the 8 in the top 40 (Turpie et al., 2002). The Swartvlei system ranks $7^{\text {th }}$. Estuarine lakes vary in the permanency of their marine connection, from permanent (e.g. Kosi) to seldom (e.g. St. Lucia), with the Swartvlei system lying between these two extremes, being open $68 \%$ of the time (1969-2016) and more frequently in summer (Russell, 2015). Salinity in estuarine lakes is determined primarily by the balance between marine and freshwater inflows (volume and timing), as well as evaporation.

Salinities in estuarine lakes can vary both spatially and temporally, with arguably the most extreme example in South

\footnotetext{
To whom all correspondence should be addressed.

e-mail: ian.russell@sanparks.org

Received 9 March 2017; accepted in revised form 10 October 2017
}

Africa being St. Lucia, where salinity ranges up to 200 (Cyrus et al., 2011) and spatial variation of salinity across the waterbody at times exceeds 100 (Taylor et al., 2006). By contrast Swartvlei Lake is usually relatively stable, with salinity fluctuation typically not exceeding 16 (1991-2006) and with little spatial variability across the waterbody (Russell, 2015).

Large fluxes in the physico-chemical characteristics of estuarine lakes can have a profound effect on biota and process (Taylor, 1983; Davies, 1982; Whitfield, 1984; Heÿl and Currie, 1985; Cyrus et al., 2011). This paper describes the effects of an 8-year period of above-average salinity, resulting from extended open mouth conditions and drought, on the submerged macrophytes and avifauna of Swartvlei Lake.

\section{METHODS}

\section{Study site}

The Swartvlei system is situated in the Garden Route National Park ( $33^{\circ} 58^{\prime}$ to $34^{\circ} 02^{\prime} \mathrm{S}$ and $22^{\circ} 43^{\prime}$ to $\left.22^{\circ} 50^{\prime} \mathrm{E}\right)$ on the Cape south coast of South Africa. It comprises two connected estuarine lakes, namely, Swartvlei Lake and so-called Karatara Lake, and the Swartvlei Estuary (Fig. 1). One small seasonal river, the Klein Wolwe (catchment area approx. $17.2 \mathrm{~km}^{2}$ ) and three larger perennial rivers, namely the Wolwe (approx. $98.3 \mathrm{~km}^{2}$ ) Hoëkraal (approx. $111.0 \mathrm{~km}^{2}$ ) and Karatara (approx. $101.6 \mathrm{~km}^{2}$ ) flow into the Swartvlei system. Mean annual rainfall in the catchments is between 900 and $1000 \mathrm{~mm} \cdot \mathrm{yr}^{-1}$ (Adamson, 1975), with no identifiable seasonal variation (Whitfield et al., 1983).

Swartvlei Lake is temporarily connected to the sea via the Swartvlei Estuary, with frequent mouth closure of the estuary caused by south-westerly wave conditions and longshore sand transport (Whitfield et al., 1983). Artificial breaching of the system is undertaken when rising water levels achieve $2.0 \mathrm{~m}$ amsl and threaten developed properties on the estuary floodplain. 


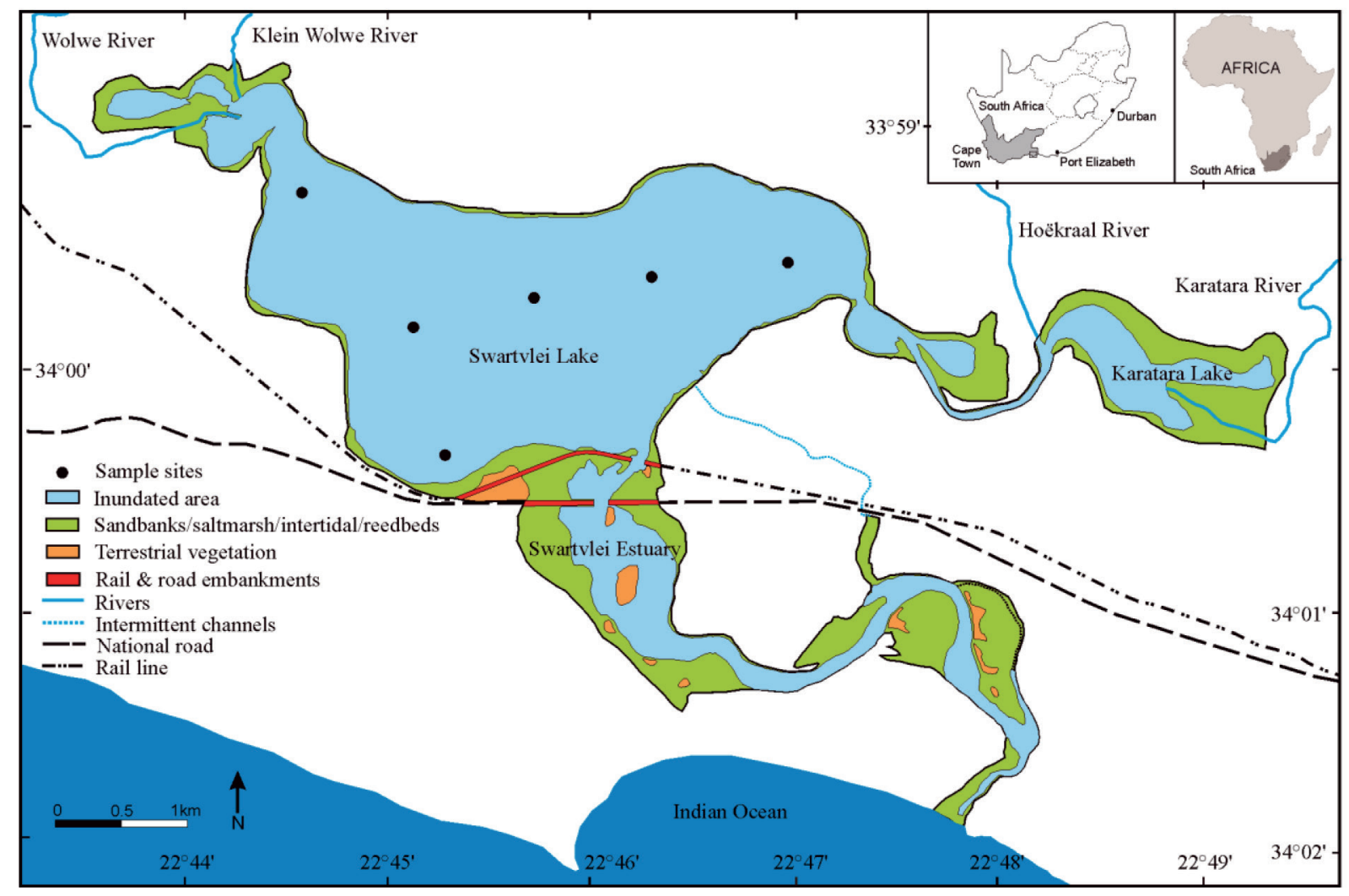

Figure 1

Locations of water quality sample sites within Swartvlei Lake over the period 1991-2016.

Swartvlei Lake is meromictic (Robarts and Allanson, 1977). The monimolimnion often has a higher salinity than the mixolimnion (Allanson and Howard-Williams, 1984). The 1\% level of photosynthetically-active radiation is generally about $5 \mathrm{~m}$ (Allanson and Howard-Williams, 1984), hence large portions of the lake, which is up to $17 \mathrm{~m}$ deep, are unable to support rooted macrophytes. Stratification is maintained by the inflow of higher salinity water from the estuary during open-mouth phases that accumulates in the deeper portions of the lake, which lie well below sea level. During closed phases, wind mixing of surface waters can cause the erosion of this stratification and, if prolonged, its breakdown (Allanson and Howard-Williams, 1984).

Submerged macrophytes are usually widespread and abundant in the shallow $(<3 \mathrm{~m})$ littoral zone of Swartvlei Lake. Communities consist predominantly of pure and mixed stands of Stuckenia pectinata syn., Potamogeton pectinatus (Fennelleaved Pondweed), Charophyta (stoneworts) and filamentous algae (Howard-Williams and Liptrot, 1980; Weisser and Howard-Williams, 1982; Whitfield et al., 1983). Estuarine and marine fish (Whitfield, 1984; Russell, 1996) and waterbirds (Boshoff et al., 1990a, 1990b, 1990c; Russell et al., 2014) inhabit the lake system.

\section{Sample collection}

Surface water salinity was measured monthly from 1991 to 1999 and quarterly from 2000 to 2016 at 6 localities (Fig. 1). Measurements were undertaken in the field during daylight hours (08:00 - 13:00) at $30 \mathrm{~cm}$ depth using YSI Model 33 (1991 to 2005) and Model 30 (2005 to 2016) S-C-T meters.

The South African Department of Water and Sanitation provided unpublished flow data for rivers. Data from the
Karatara River were used for flow descriptions, as they were the most complete. Monthly flow trends in the adjacent systems are likely to be similar because river catchments are relatively small, arise in the Outeniqua Mountain chain and are hence similarly affected by rainfall events.

The standing biomass of submerged macrophytes was determined during May and June from 1991 to 2016. Assessments were undertaken biennially between 2000 and 2004. Stratified random sampling was used to position 6 littoral transects around the lake, the limits of which were the inner edge of the emergent macrophyte zone and the $2 \mathrm{~m}$ depth contour. A submerged macrophyte sampler (Howard-Williams and Longman, 1976) was used to collect the above-ground portions of macrophytes at five $0.0625 \mathrm{~m}^{2}$ sample points along the length of each transect. Living plant tissue was oven-dried at $55^{\circ} \mathrm{C}$ for approximately 7 days and weighed to the nearest gram on an electronic balance.

Waterbird abundance was determined biannually during summer (January-February) and winter (July-August) from 1992 to 2016. Counts were conducted by 4 observers using field glasses, from a boat following a standardised route. The route allowed for surveillance of all open water areas, as well as an estimated 90 to $95 \%$ of marginal areas with emergent macrophytes. Variability in observer error was minimised by use of the same observers wherever possible throughout the study period, with observers specialising in different taxa. Mean biomass of waterfowl from summer and winter abundance assessments within a calendar year was taken to represent annual average biomass. Biomass of waterbird species was calculated from the mean of the masses for males and females obtained from Fairall (1981) for Fulica cristata (Red-knobbed Coot) and Hockey et al. (2005) for the other species. 


\section{Analysis}

Salinity did not differ significantly between sample sites (Russell 2015); therefore, mean salinity of all sites was used to display change in salinity over time. The association between the waterbird and macrophyte biomass was examined using regression analysis.

\section{RESULTS}

River runoff broadly correlates with rainfall, with low rainfall periods resulting in periods of sustained low runoff (2009) and, alternatively, high rainfall years (2006-2007) resulting in high runoff, which typically includes one or more high-intensity flooding events (Fig. 2a, b). High runoff events during closed phases leading to a rapid rise in water level in the system invariably triggered artificial breaching of the estuary mouth. High freshwater inflow events during closed phases result in a reduction in lake salinity (Fig. 2b, c), though this is short-term if followed by breaching which enables the inflow of marine waters into the system once river flow has subsided. Progressive increases in salinity in Swartvlei Lake are usually associated with extended open phases (Fig. 2b, c), with decreases in
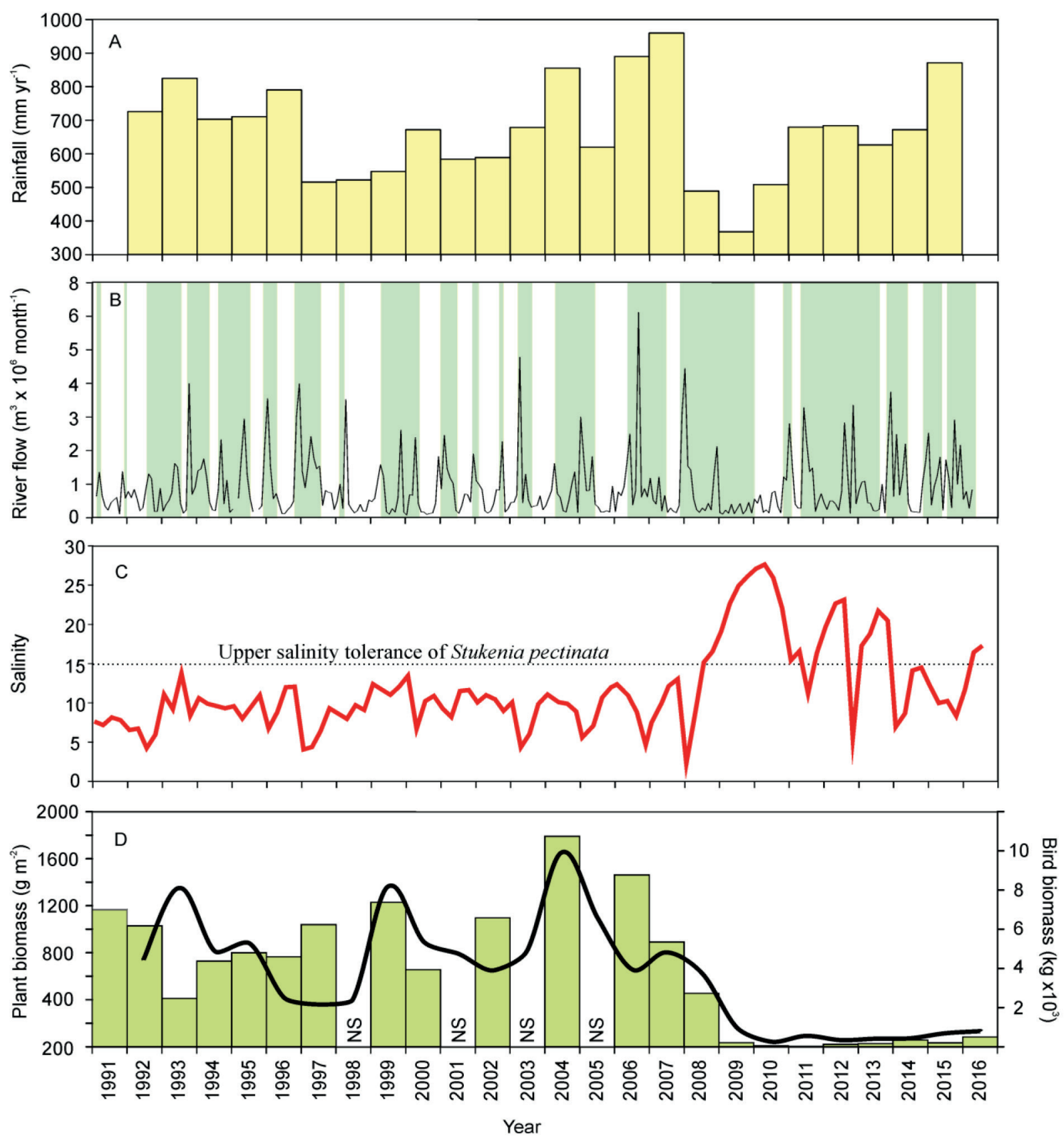

Figure 2

(A) Total annual rainfall (1991-2015) measured at Rondevlei $2^{\text {nd }}$ order meteorological station. (B) Time-series of the total monthly flow in the Karatara River. Shaded vertical bars indicate periods when the Swartvlei Estuary was open. (C) Time series of the average salinity of surface mixolimnion waters in Swartvlei Lake measured at 3-month intervals from 1991 to 2016 (D) Solid line indicates total biomass of all waterbirds on Swartvlei Lake averaged from surveys conducted bi-annually in January and July. Shaded vertical bars indicate the biomass of submerged macrophytes determined annually in the period of maximum biomass (May-June). NS = macrophytes not sampled. 
salinity at times associated with extended closed phases, but more commonly associated with high freshwater inflows during both closed and open phases.

During the period 1991 to 2007 surface salinity typically fluctuated between 5 and 12 (Fig. 2c), with occasional deviations beyond this range being short-lived and generally associated with high freshwater inflows $(<5)$ or extended open conditions (>12). A high-intensity rainfall event occurred in November 2007 (Fig. 2b) with $260 \mathrm{~mm}$ falling in a 48-h period (Rondevlei meteorological station). Salinity of surface waters in Swartvlei Lake dropped from 13.1 to 2.3 during this event (Fig. 2c). Swartvlei Estuary was breached on 22 November 2007, and remained open until 4 January 2010. This extended open phase coincided with a period of exceptionally low rainfall in 1999 (Fig. 2b), which together resulted in a substantial increase in the salinity of the lake's surface waters (2.3 to a high of 27.6) during the 775 days the estuary was open (Fig. 2c). Higher than average salinity also occurred during much of the period 2011 to 2013 (Fig. 2c), when the estuary also remained open for an extended period $(\max =831$ consecutive days) (Fig. $2 b)$, with short-term decreases occurring only during high-runoff events.

The biomass of submerged macrophytes in Swartvlei Lake littoral decreased substantially during the period of increasing and high salinity, declining from $892.0 \mathrm{~g} \cdot \mathrm{m}^{-2}$ in 2007 prior to salinity increases, to $34.8 \mathrm{~g} \cdot \mathrm{m}^{-2} 2$ years later in 2009 during the low freshwater inflow period, and reaching a low of $3.0 \mathrm{~g} \cdot \mathrm{m}^{-2}$ in 2011 (Fig. 2d). This equated to a 99\% decline in standing crop. Exceptionally low plant biomass has persisted up until 2016, though with some relatively small increases (3.0 to $83.7 \mathrm{~g} \cdot \mathrm{m}^{-2}$ ) during this 5-year period (Fig. 2d).

A substantial decline in the biomass of waterbirds coincided with the decline of submerged macrophytes (Fig. 2d). The biomass of all waterbirds in Swartvlei Lake decreased from 4 $775 \mathrm{~kg}$ in 2007 to $217 \mathrm{~kg} 3$ years later in 2010, representing a $95 \%$ decrease. Low overall waterbird biomass has persisted up until 2016. A significant $(F=26.996, p<0.000)$ regression is present between plant biomass and the biomass of all waterbirds. Both piscivorous waterbirds and the predominantly herbivorous waterfowl underwent declines (Fig. 3a, b). The mean biomass of waterfowl during years prior to plant declines
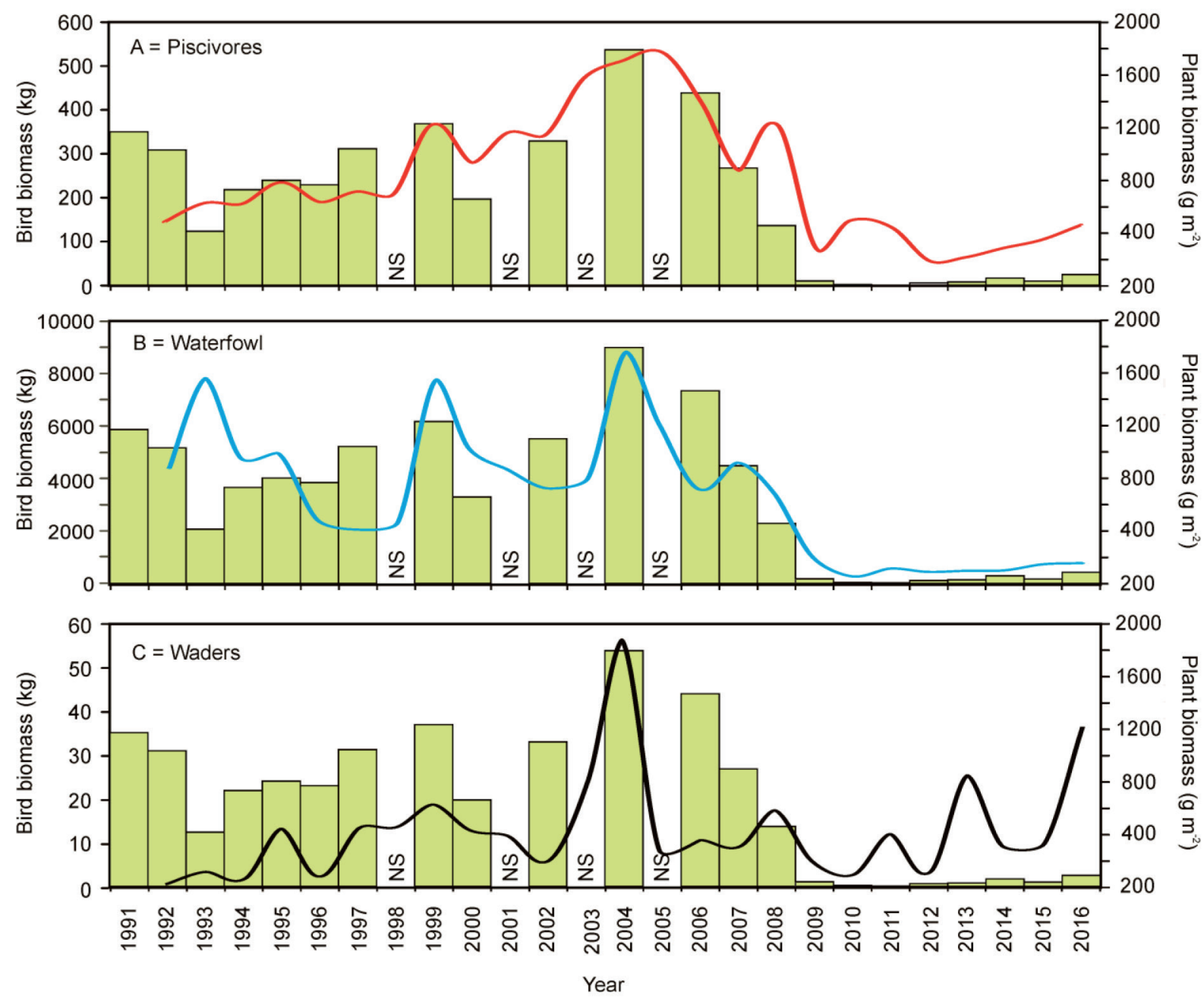

Figure 3

(A-C) Solid lines indicates total biomass of (A) piscivorous waterbirds comprising grebes, cormorants, darter, herons, egrets, night heron, bittern, raptors, gulls, terns and kingfishers, (B) waterfowl comprising ducks, geese, crake, swamphen, moorhen and coot, (C) waders comprising ibises, spoonbill, rail, jacana, oystercatcher, plovers, sandpipers, lapwing, greenshank, stint, ruff, snipe, avocet, stilt and thick-knee on Swartvlei Lake. Annual totals are averaged from surveys conducted bi-annually in January-February and July-August. Shaded vertical bars in all panels indicate the biomass of submerged macrophytes in Swartvlei Lake determined annually in the period of maximum biomass (May-June). NS = macrophytes not sampled. 
(1992-2007) was $4684 \mathrm{~kg}$, which decreased to an average of $403 \mathrm{~kg}$ during the phase of low plant abundance (2009-2016), equating to a decline of $91 \%$. Regression between plant biomass and the biomass of waterfowl is significant $(F=24.470$, $p<0.000)$. Over the same period, the biomass of piscivorous waterbirds declined from $304 \mathrm{~kg}$ to $99 \mathrm{~kg}$, equating to a decline of $67 \%$. Regression between plant biomass and the biomass of piscivorous waterbirds is highly significant $(F=48.970$, $p<0.000)$. By contrast, the mean biomass of wading birds, excluding greater flamingos which occur intermittently, though at times in sufficiently large numbers to completely dominate wader biomass, remained low (average $=12.8 \mathrm{~kg}$ ) during both high and low macrophyte biomass phases (Fig. 3c). No significant correlation existed between plant biomass and wader biomass $(F=1.890, p=0.185)$.

\section{DISCUSSION}

The upper salinity tolerance of the dominant macrophytes S. pectinata and Charophyta is considered to be 15 (HowardWilliams and Liptrot, 1980). It is presumed that the prolonged exposure of these species to high salinities in Swartvlei Lake from 2008 onwards was the cause of their temporarily corresponding dieback. The close link between zoobenthos and submerged macrophytes in Swartvlei Lake has been demonstrated by Davies (1982), when in the 1980s macrophyte senescence over a 3 -year period, characterised by a $60 \%$ decline in primary production (Taylor, 1983), resulted in a $74 \%$ decline in littoral invertebrate biomass, reducing food availability for invertebrate-feeding fish and birds. An analogous decline could be expected to have occurred post-2007 which, due to dominant taxa and diatoms being tolerant of high salinities (Nel et al., 2015; Bate et al., 2013), would likely have been due to the loss of macrophytes and associated detritus production.

Most waterfowl (ducks and rallids) are dependent on macrophytes, either directly or indirectly, for food. The most abundant of these waterfowl on Swartvlei Lake is the Red-knobbed Coot (Russell et al., 2014), which feeds almost exclusively on $S$. pectinata and Chara spp. (Fairall, 1981). Of the 7 duck species that have been regularly recorded, 5 (Anas undulata Yellowbilled Duck, Anas erythrorhyncha Red-billed Teal, Netta erythropthalma Southern Pochard, Thalassornis leuconotus Whitebacked Duck, and Alopochen aegyptiaca Egyptian Goose) are primarily herbivorous (Siegfried, 1981; Brickell, 1988), though the Egyptian Goose feeds predominantly on terrestrial vegetation (Halse, 1984). Aquatic invertebrates form the major component of the diet of Anas smithii (Cape Shoveler) and Anas capensis (Cape Teal) (Siegfried, 1981; Brickell, 1988). The relationship between macrophyte biomass and both herbivorous and invertebrate-feeding waterfowl has been demonstrated in the Wilderness lakes (Russell et al., 2009), and the substantial decline in waterfowl on Swartvlei Lake can with some confidence be ascribed to a local decline in their food source.

Estuarine fishes are able to tolerate salinity ranges in excess of those recorded in Swartvlei Lake (Whitfield, 1998). The diet of many estuarine fishes, however, is linked to the presence of macrophytes, with juveniles and adults of numerically dominant littoral species (Whitfield, 1984) such as Rhabdosargus holubi (Cape Stumpnose) feeding mainly on filamentous algae, macrophytes and epibenthic invertebrates (Whitfield, 1984, 1986). The abundant Monodactylis falciformis (Oval Moony) feed on invertebrates associated with macrophytes (Whitfield, 1984), and the diet of Mugilidae (mullet spp.) comprises mainly plant detritus and associated unicellular algae and diatoms
(Whitfield, 1982). A substantial decline in macrophytes is thus expected to result in an associated decline in littoral fish populations, as observed by Whitfield (1984) in Swartvlei Lake in the early 1980s. Abundant zooplanktivorous species such as Atherina breviceps (Cape Silverside) and Gilchristella aestuarius (Estuarine Round-herring) (Whitfield, 1984) are likely to be less affected. Although changes in littoral fish communities were not assessed in this study, their probable decline following prolonged macrophyte senescence could account for substantial declines in piscivorous waterbirds.

Howard-Williams and Allanson (1979) described how the ratio of food production to consumption in Swartvlei Lake is approximately 1:1 and hypothesized that any change in production would have a corresponding change in the number of consumer organisms. The significant positive correlations between macrophyte plant biomass and the biomass of waterbirds either directly or indirectly dependent on littoral plants supports this hypothesis.

The question arises whether the observed changes are likely to persist over the long term. Expectations are that cyclical rainfall patterns, including the reduction of the El Niño phenomenon, could, in the short term, lead to periods of aboveaverage rainfall and hence freshwater inflows. In addition, the periods of atypically prolonged open estuary phases following large-scale flooding in 2006 and 2007, and as also observed following floods in 1980 (Whitfield et al., 1983), could also be expected to decline, resulting in future shorter open phases. These two processes would result in deceasing salinity, and the possible shifting of the system back to a state where macrophytes intolerant of high salinity re-establish, and in turn support, either directly or indirectly, a high biomass of waterbirds.

Alternatively, the current changes that are occurring in Swartvlei Lake may provide a glimpse of what the long-term future holds for this system. Climate change and resulting changes in the marine environment, such as sea level rise and increased hydrostatic, wave and wind set-up, will affect estuaries in several ways, including increased intrusion of seawater (Theron and Rossouw, 2008). Although pollen analysis of the adjacent Groenlvlei Lake sediments provides some evidence to suggest that global cooling is associated with drier conditions in the southern Cape (Martin, 1968), and hence by default global warming is associated with wetter conditions, climate change models widely forecast increases in the intensity and frequency of droughts in South Africa resulting from global warming (Cook et al., 2014; Dia, 2013), with only the eastern subtropical portions of the country likely to experience generally wetter conditions (Engelbrecht et al., 2009; Shongwe et al., 2009; Tadross et al., 2005). Thus periodic reduction in rainfall and river flow, coupled with increased abstraction of freshwater from rivers to meet growing demand, in conjunction with increased seawater intrusion, may place Swartvlei Lake on a trajectory of becoming more saline more frequently.

If the above scenario plays out it is unsure if existing biota will adapt, or if more salinity-tolerant species will establish or dominate. The epiphytic Brachidontes virgiliae (Brackwater Mussel) which is the dominant bivalve in the system (Davies, 1982), comprising 95 to $99 \%$ of the benthic standing stock (Allanson, 1981), has a preferred salinity tolerance range of 0 to 20 , though is able to survive salinities in excess of seawater ( $\sim 35)$ when exposure to increasing concentration is gradual (Nel et al., 2015). Similarly, epipelic diatoms show a high tolerance to variability in salinity (Bate et al., 2013). Thus, given appropriate substrate and food sources they possibly could persist. However, it is unsure if current $S$. pectinata and Chara 
spp. dominated macrophyte communities would be replaced by species that are abundant in the typically more saline Swartvlei Estuary, such as Ruppia cirrhosa (Spiral Ditchgrass) or Zostera capensis (Eelgrass), which can tolerate salinity levels up to 50 and 45, respectively (Adams and Bate, 1994), or whether they would be able to support comparable waterbird and other estuarine biota communities.

Humphries et al. (2016) have provided evidence of historic ( 1 100 and 1750 cal year BP) severe drought events in St Lucia to the north, demonstrating that El Niño driven desiccation cycles and resultant elevated salinity are a long-standing natural process, and a driver of environmental flux in systems sensitive to changes in water balance. Even though long-term (25-year) data indicate that the Swartvlei system, including Swartvlei Lake, is not undergoing a rapid deterioration in water quality (Russell, 2015), but rather exhibiting both short- and long-term fluxes characteristic of estuarine systems, these results do emphasise the ability of Swartvlei Lake to undergo substantial changes in ecological state. This in turn emphasises the need for wise use of resources, particularly freshwater, and awareness of the consequences of radically altering estuarine processes, such as artificial estuary breaching, lest we wish to observe ecological changes that become either a more regular occurrence, or possibly even a permanent state.

\section{ACKNOWLEDGEMENTS}

The funding of this work by the South African National Parks is gratefully acknowledged. Several persons assisted with waterbird surveys, though the longest serving team members were Bridget Randall, Nick Hanekom and Beata Sachse. Eddie Kivett and Bheki Maphanga assisted during the majority of plant and water quality surveys. Comments by two anonymous reviewers have helped to improve the paper.

\section{REFERENCES}

ADAMS JB and BATE GC (1994) The ecological implications of tolerance to salinity by Ruppia cirrhosa (Petagna) Grande and Zostera capensis Setchell. Bot. Mar. 37 (5) 449-456. https://doi.org/10.1515/ botm.1994.37.5.449

ADAMSON PT (1975) Extension of monthly runoff records in the catchments of the Wit Els, Diep and Karatara rivers - Wilderness Cape Province. Department of Water Affairs, Pretoria.

ALLANSON BR (1981) The coastal lakes of southern Africa. In: Day JH (ed.) Estuarine Ecology with Particular Reference to Southern Africa. AA Balkema, Cape Town.

ALLANSON BR and HOWARD-WILLIAMS C (1984) A contribution to the physico-chemical limnology of Swartvlei. Arch. Hydrobiol. 99 133-159.

BATE GC, SMAILES PA and ADAMS JB (2013) Epipelic diatoms in the estuaries of South Africa. Water SA 39 (1) 205-118. https://doi org/10.4314/wsa.v39i1.11

BAYLEY S, STOTTS VD, SPRINGER PF and STEENIS J (1978) Changes in submerged aquatic macrophyte populations at the head of Chesapeake Bay, 1958-1975. Estuaries 1 171-182. https://doi. org/10.2307/1351459

BOSHOFF AF, PALMER NG and PIPER SE (1991a) Spatial and temporal abundance patterns of waterbirds in the southern Cape Province. Part 1: Diving and surface predators. Ostrich 62 156-177. https://doi.org/10.1080/00306525.1991.9639655

BOSHOFF AF, PALMER NG and PIPER SE (1991b) Spatial and temporal abundance patterns of waterbirds in the southern Cape Province. Part 2: Waterfowl. Ostrich 62 178-196. https://doi.org/10. 1080/00306525.1991.9639656

BOSHOFF AF, PALMER NG and PIPER SE (1991c) Spatial and temporal abundance patterns of waterbirds in the southern Cape
Province. Part 3: Wading birds. Ostrich 62 197-214. https://doi.org/ 10.1080/00306525.1991.9639658

BRICKELL N (1988) Ducks, Geese and Swans of Africa and its Outlying Islands. Frandsen Publishers, Fourways. 228 pp.

COOK BI, SMERDON JE, SEAGER R and COATS S (2014) Global warming and $21^{\text {st }}$ century drying. Clim. Dyn. 43 2607-2627. https:// doi.org/10.1007/s00382-014-2075-y

CYRUS D, JERLING H, MACKAY F and VIVIER L (2011) Lake St Lucia, Africa's largest estuarine lake in crisis: Combined effects of mouth closure, low levels and hypersalinity. S. Afr. J. Sci. 107 (3/4) 1-13. https://doi.org/10.4102/sajs.v107i3/4.291

DAVIES BR (1982) Studies on the zoobenthos of some southern Cape coastal lakes. Spatial and temporal changes in the benthos of Swartvlei, South Africa, in relation to changes in the submerged littoral macrophyte community. J. Limnol. Soc. South. Afr. 8 33-45. https://doi.org/10.1080/03779688.1982.9633232

DIA A (2013) Increasing drought under global warming in observations and models. Nat. Clim. Change 3 52-58.

ENGELBRECHT FA, McGREGOR JL and ENGELBRECHT CJ (2009) Dynamics of the Conformal-Cubic Atmospheric Model projected climate-change signal over southern Africa. Int. J. Climatol. 29 1013-1033. https://doi.org/10.1002/joc.1742

FAIRALL N (1981). A study of the bioenergetics of the Red-knobbed Coot Fulica cristata on a South African estuarine lake. S. Afr. J. Wildlife Res. 11 1-4.

HALSE SA (1984) Diet, body condition and gut size of Egyptian Geese. J. Wildlife Manage. 48 569-573. https://doi.org/10.2307/3801191

HEŸL CW and CURRIE MH (1985) Variations in the use of the Bot River Estuary by water-birds. Trans. R. Soc. S. Afr. 45 397-417.

HOCKEY PAR, DEAN WRJ and RYAN WRJ (eds) (2005) Roberts Birds of Southern Africa ( $7^{\text {th }}$ edn). The Trustees of the John Voelcker Bird Book Fund, Cape Town, South Africa. 1296 pp.

HOWARD-WILLIAMS C and ALLANSON BR (1979) The ecology of Swartvlei: research for planning and future management. Water Research Commission, Pretoria.

HOWARD-WILLIAMS C and LIPTROT MRM (1980) Submerged macrophyte communities in a brackish South African estuarine-lake system. Aquat. Bot. 9 101-116. https://doi. org/10.1016/0304-3770(80)90012-1

HOWARD-WILLIAMS C and LONGMAN M (1976) A quantitative sampler for submerged aquatic macrophytes. J. Limnol. Soc. South. Afr. 2 31-33. https://doi.org/10.1080/03779688.1976.9632918

HUMPHRIES MS, GREEN AN and FINCH JM (2016) Evidence of El Niño driven desiccation cycles in a shallow estuarine lake: The evolution and fate of Africa's largest estuarine system, Lake St Lucia. Glob. Planet. Change 147 97-105. https://doi.org/10.1016/j. gloplacha.2016.11.002

LAZAR AC and DAWES CJ (1991) A seasonal study of the seagrass Ruppia maritima L. in Tampa Bay, Florida. Organic constituents and tolerances to salinity and temperature. Bot. Mar. 34 265-269. https://doi.org/10.1515/botm.1991.34.3.265

MARTIN ARH (1968) Pollen analysis of Groenvlei lake sediments, Knysna (South Africa). Rev. Palaeobot. Palynol. 7 107-144. https:// doi.org/10.1016/0034-6667(68)90029-8

NEL HA, PERISSINOTTO R and TAYLOR RH (2015) Effects of salinity on the survival of the Brackwater Mussel, Brachidontes virgiliae, in the St Lucia estuarine system, South Africa. Water SA 41 (1) 15-20. https://doi.org/10.4314/wsa.v41i1.3

QUAMMEN ML and ONUF CP (1993) Laguna Madre: Seagrass changes continue decades after salinity reduction. Estuaries 16 302-310. https://doi.org/10.2307/1352503

ROBARTS RD and ALLANSON BR (1977) Meromixis in the lakelike upper reaches of a South African estuary. Arch. Hydrobiol. 80 531-540.

RUSSELL IA (1996) Fish abundance in the Wilderness and Swartvlei Lake systems: changes relative to environmental factors. S. Afr. J. Zool. 31 1-9. https://doi.org/10.1080/02541858.1996.11448389

RUSSELL IA (2015) Spatio-temporal variability of surface water quality parameters in the Swartvlei estuarine lake system, South African. Afr. J. Aquat. Sci. 40 (2) 119-131. https://doi.org/10.2989/1 6085914.2015.1029868

RUSSELL IA, RANDALL RM, RANDALL BM and HANEKOM

http://dx.doi.org/10.4314/wsa.v43i4.14

Available on website http://www.wrc.org.za

ISSN 1816-7950 (Online) = Water SA Vol. 43 No. 4 October 2017

Published under a Creative Commons Attribution Licence 
N (2009) Relationships between the biomass of waterfowl and submerged macrophytes in a South African estuarine lake system Ostrich 80 (1) 35-41. https://doi.org/10.2989/ OSTRICH.2009.80.1.5.763

RUSSELL IA, RANDALL RM and HANEKOM N (2014) Spatial and temporal patterns of waterbird assemblages in the Wilderness Lakes Complex, South Africa. Waterbirds 37 (1) 1v18.

SHONGWE ME, VAN OLDENBORGH GJ, VAN DEN HURK BJJM, DE BOER B, COELHO CAS and VAN AALST MK (2009) Projected changes in mean and extreme precipitation in Africa under global warming. Part I: Southern Africa. J. Clim. 22 3819-3837. https:// doi.org/10.1175/2009JCLI2317.1

SIEGFRIED WR (1981) The estuarine avifauna of southern Africa. In: Day JH (ed) Estuarine Ecology with Particular Reference to Southern Africa. AA Balkema, Cape Town.

TADROSS M, JACK C and HEWITSON B (2005) On RCM-based projections of change in southern African summer climate. Geophys. Res. Lett. 32 1-4. https://doi.org/10.1029/2005GL024460

TAYLOR D (1983) The effects of a major macrophyte regression upon primary production in the littoral of Swartvlei. Arch. Hydrobiol. 96 345-353.

TAYLOR R, ADAMS JB and HALDORSEN S (2006) Primary habitats of the St. Lucia Estuarine System, South Africa, and their responses to mouth management. Afr. J. Aquat. Sci. 31 (1) 31-41. https://doi. org/10.2989/16085910609503869

THERON A and ROSSOUW M (2008) Analysis of potential coastal zone climate change impacts and possible response options in the southern African region. In: Proc. Science Real and Relevant: 2nd CSIR Biennial Conference, 17-18 November 2008, Pretoria.

TURPIE JK, ADAMS JB, JOUBERT A, HARRISON TD, COLLOTY BM, MAREE RC, WHITFIELD AK, WOOLDRIDGE TH, LAMBERTH SJ, TALJAARD S and co-authors (2002) Assessment of the conservation priority status of South African estuaries for use in management and water allocation. Water SA 28 (2) 191-206. https://doi.org/10.4314/wsa.v28i2.4885

VAN NIEKERK L and TURPIE JK (eds) (2012) South African National Biodiversity Assessment 2011: Technical Report. Volume 3: Estuary Component. CSIR Report Number CSIR/NRE/ECOS/ ER/2011/0045/B. Council for Scientific and Industrial Research, Stellenbosch.

VAQUER A and HEURTEAUX P (1989) Recent modifications of the aquatic vegetation in the Etang du Vaccares, Camargue, France in relation with the human disturbances. Annal. Limnol. 25 25-38. https://doi.org/10.1051/limn/1989002

VERHOEVEN JTA (1975) Ruppia-communities in the Camargue, France. Distribution and structure in relation to salinity and salinity fluctuations. Aquat. Bot. 1 217-241. https://doi. org/10.1016/0304-3770(75)90024-8

VERHOEVEN JTA and VAN VIERSSEN W (1978a) Distribution and structure of communities dominated by Ruppia, Zostera and Potamogeton species in the inland waters of de Bol, Texel, The Netherlands. Estuar. Coast. Mar. Sci. 6 417-428. https://doi. org/10.1016/0302-3524(78)90132-9

VERHOEVEN JTA and VAN VIERSSEN W (1978b) Structure of macrophyte dominated communities in two brackish lagoons and the island of Corsica, France. Aquat. Bot. 5 77-86. https://doi. org/10.1016/0304-3770(78)90048-7

WEISSER PJ and HOWARD-WILLIAMS C (1982) The vegetation of the Wilderness Lakes System and the macrophyte encroachment problem. Bontebok 2 19-40.

WHITFIELD AK (1982) Trophic relationships and resource utilization within the fish communities of the Mhlanga and Swartvlei estuarine systems. PhD thesis, University of Natal.

WHITFIELD AK (1984) The effects of prolonged aquatic macrophyte senescence on the biology of the dominant fish species in a southern African coastal lake. Estuar. Coast. Shelf Sci. 18 315-329. https://doi.org/10.1016/0272-7714(84)90074-X

WHITFIELD AK (1986) Fish community structure response to major habitat changes within the littoral zone of an estuarine coastal lake. Environ. Biol. Fish. 17 41-51. https://doi.org/10.1007/BF00000399

WHITFIELD AK (1995) Available scientific information on individual South African estuarine systems. WRC Report No. 577/1/95. Water Research Commission, Pretoria.

WHITFIELD AK (1998) Biology and Ecology of Fishes in Southern African Estuaries. J.L.B. Smith Institute of Ichthyology, Grahamstown. 223 pp.

WHITFIELD AK, ALLANSON BR and HEINECKEN THE (1983) Estuaries of the Cape, Swartvlei (CMS 11). Report No. 22. In: Heydorn AEF and Grindley JR (eds), Estuaries of the Cape. Part II: Synopses of available information on individual systems. CSIR Research Report 421. Council for Scientific and Industrial Research. Stellenbosch. 